\title{
A Review of Recent Trend of COVID-19 Infection and Correlation with Pulmonary Function
}

\author{
Min Woo Kim ${ }^{1,2 \dagger, *}$ \\ ${ }^{1}$ Department of Surgery, Yonsei University College of Medicine, Seoul 03772, Korea \\ ${ }^{2}$ Department of Biomedical Laboratory Science, Yonsei University, Wonju 26493, Korea
}

\begin{abstract}
Coronavirus is generally known to cause minor respiratory diseases in animals and humans. However, some coronavirus genus is reported to cause animal-to-human interspecies infection. Since the end of 2019, a new type of coronavirus (COVID-19) infection is spreading rapidly throughout the world, leading to the declaration of the pandemic by the World Health Organization (WHO). Despite various clinical studies to counter COVID-19 infection, the total confirmed cases and death rates are still accumulating. To break down this new threat, we should pay attention to newly revealed information based on scientific facts. In this review, we introduced the clinical characteristics, diagnostic methods, and treatment of patients infected with COVID-19. Moreover, we highlighted the correlation between COVID-19 severity and patients with underlying diseases. Potential risks associated with COVID-19 can be differed depending on the condition of patients and can cause pulmonary complications. Therefore, lung capacity exams are expected to help predict the progression of the disease along with previously established detection methods such as molecular diagnostics and immunoassay. Although physiological research hasn't yet been emphasized to evaluate COVID-19 infection, this review is expected to be valuable to give new inspiration to deal with COVID-19 which might strike again in the future.
\end{abstract}

Key Words: COVID-19, SARS-CoV-2, Pulmonary function, Clinical characteristics

\section{서 론}

새로운 코로나바이러스(COVID-19, SARS-CoV-2, 2019$\mathrm{nCoV}$ ) 무서운 속도로 확산되면서 2020년 3월 11일 세계 보건기구(WHO; World Health Organization)가 이를 세계적 유행병(pandemic)이라고 선언하였다(Cucinotta and Vanelli, 2020). COVID-19 감염의 최초 발생은 2019년 12월 중국 후베이성 우한시로부터 시작하여, 불과 반년이 채 지나지 않아 2020년 5월 15일 기준 전세계적으로 총 434만명의 확진자, 155 만명의 완치자, 30 만명의 사망자를 기록하였다 (Roser et al., 2020). COVID-19는 단일 RNA (single stranded)
계열 바이러스이며 2002년, 2012년에 보고되었던 중증급 성호흡기증후군(SARS, SARS-CoV-1)과 중동호흡기증후군 (MERS, MERS-CoV)의 원인으로 밝혀진 바이러스들과 같 은 군에 속한다(Giwa et al., 2020). 21세기 들어 다시 맞이 한 COVID-19 호흡기 바이러스의 급속한 국제적 확산은 심각한 전세계 공중보건 비상사태를 야기하였다(Fig. 1A). 현재까지 보고된 감염자의 임상증상은 무증상부터 일부 개인에서 사망에 이를 수 있는 중증까지 다양하며 어떤 개인에게도 감염을 일으킬 수 있다(Ma et al., 2020; Sun et al., 2020). COVID-19는 SARS나 MERS와 매우 유사하 게 마른 기침, 발열, 근육통, 인후염, 호흡곤란 등의 증상 을 나타낸다. 더불어 만성폐쇄성폐질환(COPD; chronic ob-

Received: May 26, 2020 / Revised: June 30, 2020 / Accepted: July 13, 2020

* Researcher.

${ }^{\dagger}$ Corresponding author: Min Woo Kim. Department of Surgery, Yonsei University College of Medicine, 50-1, Yonsei-ro, Seodaemun-gu, Seoul 03722, Korea. Tel: +82-10-6861-7085, e-mail: nanodream89@gmail.com

(C) The Korean Society for Biomedical Laboratory Sciences. All rights reserved.

(c) This is an Open Access article distributed under the terms of the Creative Commons Attribution Non-Commercial License (http://creativecommons.org/licenses/by-nc/3.0/) which permits unrestricted non-commercial use, distribution, and reproduction in any medium, provided the original work is properly cited. 
A

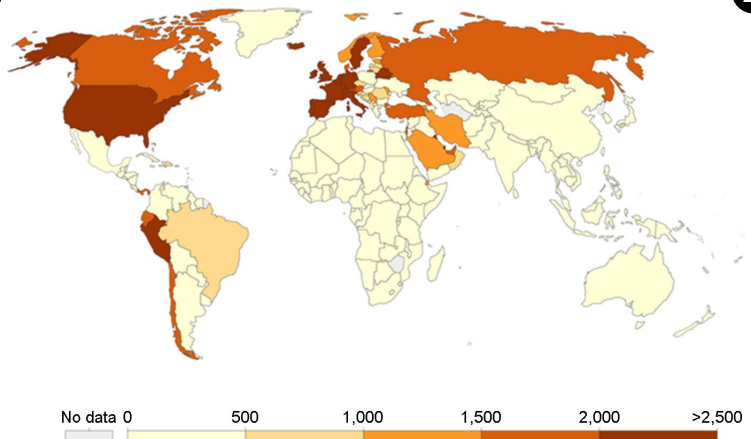

B

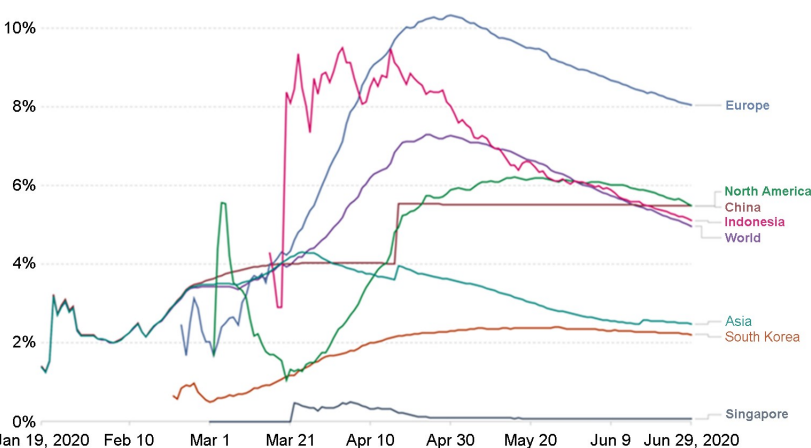

Fig. 1. Total confirmed COVID-19 cases (A) and death rates (B) till May 15, 2020. The results may not be an accurate count of the true number due to limited testing. Data sources has been downloaded from European Centre for Disease Prevention and Control (ECDC).

structive pulmonary disease), 제한성폐질환, 폐암과 같은 기 저질환자나 60 세 이상의 노년층이 감염에 더 취약하며 예 후가 좋지 않다는 보고가 있다(Nikolich-Zugich et al., 2020). 비록 아직까지 명확한 감염 경로 또는 치료법은 밝혀진 바 없으나 현재 전세계적으로 연구가 집중되고 있어서 앞 으로 COVID-19 감염증에 대한 이해가 점차 늘어날 것으 로 예상된다.

COVID-19의 치사율(CFR; case fatality rate)은 세계 평균 $5 \sim 6 \%$ 정도로 추정되어 $10 \%, 30 \%$ 대의 치사율을 보였던 $\mathrm{SARS}$ 와 MERS보다는 낮지만 확산 속도는 더 빠르다는 차이점이 있다(Chan-Yeung and Xu, 2003; Rasmussen et al., 2016; Bulut and Kato, 2020). 현재 비교적 초기의 발병이 시작된 중국(5.5\%), 대한민국(2.2\%), 인도네시아 $(5.1 \%)$ 등 동아시아 지역은 평균 $2.5 \%$ 의 치사율을 기록하며 감염이 소강상태(2020년 6월 29일 기준)에 접어들었고, 유럽(8.0\%), 북미(5.4\%) 지역에서는 $4-5$ 월 들어 $10 \%$ 에 가까운 높은 치사율을 보이며 급속하게 감염이 확산되었다가 점차 감 소하는 추세에 있다. 싱가포르는 꾸준히 $1 \%$ 미만의 낮은 치사율을 나타내 성공적으로 COVID-19의 확산을 억제했 다 평가 받는다(Fig. 1B). 대한민국 역시 정부, 의료진, 방 역 당국의 노력과 지역사회의 적극적인 협력으로 비교적 초기 대응을 효율적으로 진행하여 많은 외신의 호평을 받 고 있다(Oh et al., 2020). 하지만 아직 COVID-19 감염증의 종식이 선언되지 않은 시점에서 본 연구는 COVID-19의 2 차 대유행을 대비할 수 있도록 현재까지 밝혀진 COVID19 의 임상 양상, 진단, 치료법 등에 대한 고찰을 하고자 한다. 특히 COVID-19 감염 환자의 예후에 미치는 폐 기 능의 중요성이 커져 감에 따라 이와 관련된 세계 연구의 흐름을 조망해 보고자 한다.
본 론

\section{COVID-19의 임상 양상}

COVID-19은 평균적으로 2 14일의 잠복기를 가지고 있으며 보통은 38도 이상의 발열(83 98\%), 마른 기침 (76 82\%), 호흡곤란(31 55\%) 등 비 특이성 증상으로 시 작한다(Huang et al., 2020; Wu et al., 2020). 그 이외에 피로 감(38.1\%), 가래(33.7\%), 두통(13.6\%), 비폐색(4.8\%), 설사 $(3.8 \%)$, 결막 충혈 $(0.8 \%)$ 등의 증상이나 심각한 경우 폐렴 이나 패혈증을 동반하기도 한다(Shi et al., 2020). 감염 후 바이러스가 증식하게 되면 면역 체계가 바이러스를 인식 해서 면역반응을 촉발시키게 되는데 주로 항원에 대응하 여 항 바이러스 작용을 하는 $\mathrm{T}$-림프구의 반응이 활성화되 며 $\mathrm{T}$-림프구가 직접 바이러스를 사멸하거나 $\mathrm{T}$-림프구 의 존성 B-림프구를 자극하여 바이러스 특이 항체를 분비한 다(Ganji et al., 2020; Saverino, 2020). 따라서 면역 기능이 정상적으로 유지되는 경우 바이러스에 노출이 되어도 감 염되지 않거나 별도의 치료없이 자가 치료될 수 있다 이는 뛰어난 면역력이 COVID-19 감염 및 증식을 막는데 있어 중요하게 작용할 수 있음을 의미한다. 최근 $\mathrm{New}$ England Journal of Medicine지에 발표된 문헌에 따르면 COVID-19 감염증 환자의 83.2\%는 림프구저하증(lymphocytopenia)을 나타내며 중증일수록 더 심해지는 경향을 보 인다 발표한 바 있다(Guan et al., 2020). T-림프구가 감소하 면 치명적인 면역반응의 불균형을 초래하고 사이토카인 폭풍(cytokine storm)을 일으키는 염증세포들을 $\mathrm{T}$ 세포가 조절하지 못함으로써 폐 손상이나 심한 경우 사망에 이르 게 할 수 있다(Mehta et al., 2020). 초기 증상 발생 이후 진 행 말기가 되면 대규모의 폐포 손상과 급성호흡곤란 증 


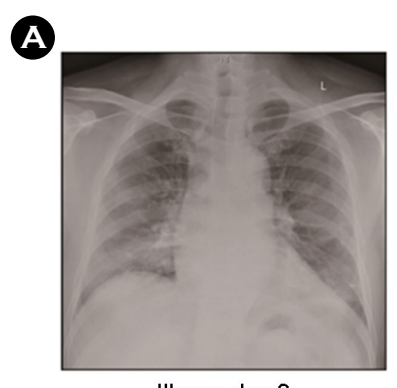

IIIness day 8

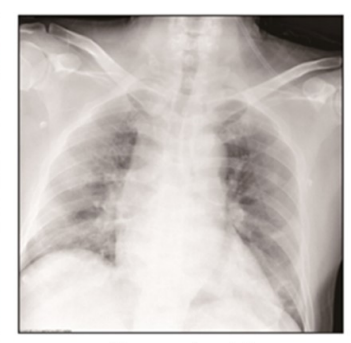

IIIness day 10

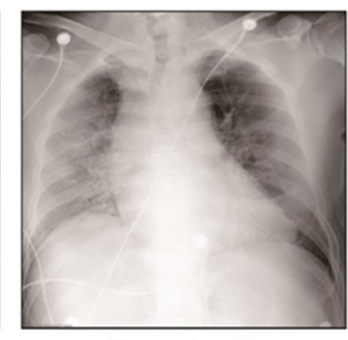

IIIness day 12

B

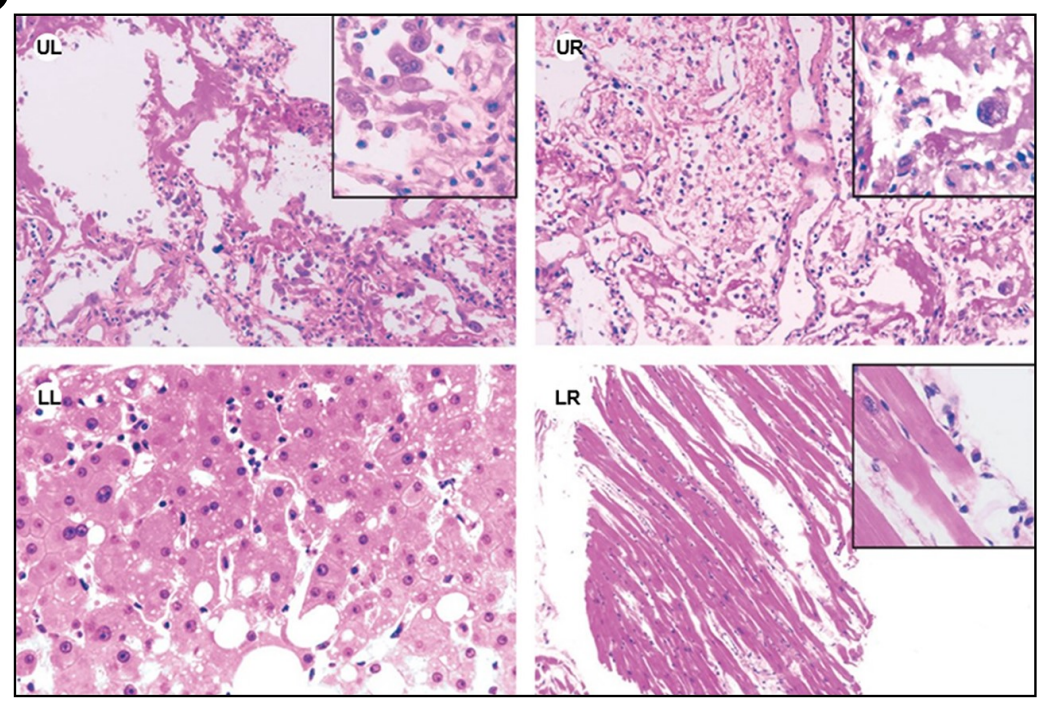

Fig. 2. Chest radiograph images in a patient with severe pneumonia caused by SARSCoV-2 (A) and pathological images of the biopsy sample. Each image represents the right lung tissue (UL) and left lung tissue (UR), liver tissue (C), and heart tissue (LR), respectively. This figure has been reproduced with permission from Elsevier (Xu et al., 2020).
후군(ARDS; acute respiratory distress syndrome)으로 환자가 사망할 수 있다(Gattinoni et al., 2020; Vittori et al., 2020).

확산 속도가 매우 빠르고 나라별로 적절한 의료 환경 이 다르기 때문에 COVID-19에 감염되어 사망한 환자의 유의미한 임상 증례 보고는 전세계적으로 아직 부족한 실 정이나 지속적으로 관련 연구가 발표되고 있다. 2020년 2월 중국 의료진이 Lancet지에 발표한 50세 남성의 증례 보고는 흉부 엑스레이 검사와 폐, 간, 심장 조직에서 나타 나는 여러 가지 병리학적 특성을 밝혔다(Xu et al., 2020). $\mathrm{X}$ 선 영상은 폐렴의 빠른 진행을 보여주었고 감염 12 일 차 양쪽 폐에 바이러스의 점진적인 침투와 격자 그림자 (gridding shadow)가 관찰되었다(Fig. 2A). 폐 조직 생검에서 는 폐포 손상과 유리질막(hyaline membrane) 형성이 뚜렷 하게 나타나 ARDS를 암시하였다. 바이러스 감염이나 치 료 약물에 의해 유도된 것으로 보이는 간 손상이 관찰되 었으며 심장 조직에서는 다른 실질적인 피해는 보고되지 않았다(Fig. 2B). 2020년 4월 미국 오클라호마에서 보고된 COVID-19 감염으로 사망한 기저질환이 있던 77세, 42세
남성의 부검 결과에서 바이러스에 의한 폐포 손상 및 기 도 염증이 관찰되었다(Barton et al., 2020). 2020년 5월 The New England Journal of Medicine에 발표된 내용에 따르면 COVID-19로 사망한 환자 7명의 폐 부검을 통해 면역세 포의 침투로 인한 폐포 손상 및 특이적으로 폐 신생혈관 생성이 증가됨을 관찰하였다(Ackermann et al., 2020). 이처 럼 폐 손상은 COVID-19 중증 환자에서 나타나는 특징이 며 질병 심각도 및 사망률과 관련된 중요한 요인이 될 수 있다. 특히 일시적인 폐 기능의 저하를 보이거나 기저질 환이 있는 환자의 경우 증상이 두드러지게 나타난다는 가 설이 설득력 있게 보고되었다(Daccord et al., 2020). 이처 럼 전세계적으로 여러 보고가 발표되고 있지만 아직까지 COVID-19 감염 자체가 모든 환자에서 심각한 폐 손상을 일으킨다는 것을 뒷받침할 증례는 부족한 실정이며 더 많 은 연구를 통해 파악해 나갈 필요가 있다.

\section{COVID-19와 폐 기능 검사}

폐에 산소를 공급하기 위해선 기류의 이동을 돕는 기 
(A)

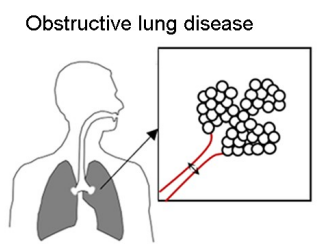

FEV1 decrease

FVC decrease or normal

FEV1/FVC decrease

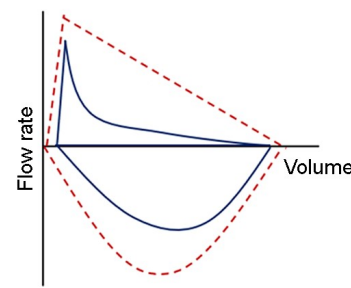

B

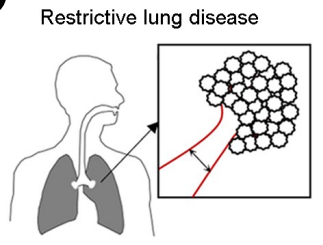

FEV1 decrease or normal FVC decrease

FEV1/FVC increase or normal

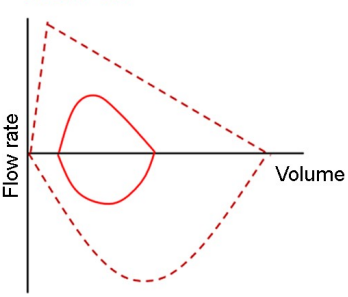

Fig. 3. Characteristics of obstructive lung disease (A) and restrictive lung disease (B) measured by spirometry. The flow-volume loop shows changes in obstructive (left) and restrictive (right) defects, with the dotted line representing the normal loop.

도(airway)가 필요하고 기도는 기관(trachea)과 두 개의 기 관지(bronchi)를 포함하며 기관지 끝은 폐포낭(alveolar sac) 에 폐포(alveoli) 뭉치가 쌍여 있는 구조로 이루어져 있다. 가스 교환은 이 폐포 벽에 인접한 작은 모세혈관을 통해 이뤄지게 된다. 일반적으로 환자의 폐 기능을 평가할 경 우 단순 폐 기능 검사(spirometry)를 하여 1초 간 노력성 호기량(FEV1), 노력성 폐활량(FVC), $\mathrm{FEV1/FVC} \mathrm{비율을} \mathrm{확}$ 인한다(Barreiro and Perillo, 2004). 가장 먼저 FEV1/FVC 비 율을 확인하며 그 비율이 정상 예측치의 $70 \%$ 이하, $\mathrm{FEV} 1$ 감소, $\mathrm{FVC}$ 가 정상 또는 감소인 경우 폐쇄성 폐질환을 의 심할 수 있고 그 그래프 곡선은 오목하게 관찰된다(Fig. $3 \mathrm{~A})$. 또한 $\mathrm{FEV} 1 / \mathrm{FVC}$ 비율이 정상 또는 증가되어 있으며 $\mathrm{FEV} 1$ 정상 또는 감소, $\mathrm{FVC}$ 감소인 경우 제한성 폐질환을 의심한다(Fig. $3 \mathrm{~B}$ ). 이처럼 기류-용적 곡선을 확인하는 것 이외에도 기관지확장제 반응 검사, 총 폐용량(TLC), 운동 검사, 폐확산기능 검사(DLCO), FEF25-75\% 소 기관지 검 사 등 폐 기능 검사법은 다양한 폐 질환을 해석하는 데 도움이 되며 COVID-19에 의한 폐 기능의 변화를 추적하 는 데 역시 유용할 것으로 생각된다.

최근 광저우인민병원에서 COVID-19 경증 환자 24명, 폐렴 동반 환자 67 명, 중증 폐렴 동반 환자 19 명을 대상 으로 한 폐 기능 검사 결과를 보고하였다(Mo et al., 2020). 병의 시작부터 폐 기능 검사까지의 기간은 각각 $20 \pm 6$ 일, $29 \pm 8$ 일, 그리고 $34 \pm 7$ 일로 퇴원 시 혈중산소포화도 $\left(\mathrm{SPO}_{2}\right)$

는 그룹 간 유의미한 차이를 보이지 않았다. 단순 폐 기능 검사 시 이상 소견을 보였던 항목은 각각 $\mathrm{DLCO} \% 51$ 건 (47.2\%), TLC\% 27건(25.0\%), FEV1\% 15건(13.6\%), FVC\% 10 건(9.1\%), FEV1/FVC 5건(4.5\%), 그리고 FEF $25-75 \%$ 8건 (7.3\%)로 나타났다. 가장 높은 비율을 보이는 DLCO 수치 는 질병의 심각도와 비례하였다. $\mathrm{TLC} \%$ 는 중증 폐렴을 동 반한 환자에서 경증 환자보다 더 낮게 측정이 되었으며 이는 질병이 심각할수록 폐 부피의 손상이 높다는 것을 의미한다. $\mathrm{FEV} 1, \mathrm{FVC}, \mathrm{FEV} 1 / \mathrm{FVC}$ 와 같은 폐 기능 수치는 환자 간 큰 차이를 보이지 않았다. 이러한 연구 결과들은 폐 기능 검사가 COVID-19 환자의 진단뿐만 아니라 추후 환자에 대한 일상적인 임상 추적에서 효과적일 수 있음을 시사한다.

2020년 5월 PLOS ONE지에 발표된 보고에 따르면 흡 연자나 만성 폐쇄성 폐질환(COPD; chronic obstructive pulmonary disease) 환자가 COVID-19 감염 확률이 증가하는 것은 아니나 COVID-19 감염이 COPD 환자와 흡연자에 대한 치사율을 높이는 것으로 나타났다(Alqahtani et al., 2020). 논문에서 보고된 COVID-19 사례 2,473건 중 COPD 를 기저질환으로 가지고 있는 환자의 비율은 $2 \%$ 로 비교 적 낮지만 질병의 심각도를 $30 \%$ 증가시켰으며 사망률은 $60 \%$ 로 매우 높았다. 같은 환자 코호트 중 $9 \%$ 의 환자 비 율을 차지하는 흡연자 그룹에서 비흡연자에 비해 $22 \%$ 증 가된 심각도와 $38 \%$ 의 사망률을 나타내어 흡연 이력이 고 려해야할 중요한 요인임을 시사했다. 매우 제한적인 데이 터이지만 폐암 이력이 COVID-19에 미치는 잠재적인 위험 성이 보고된 적 있다(Liang et al., 2020). 하지만 COVID-19 감염 이후 호흡기 재활은 전략적으로 활용될 수 있으며 실제로 COPD, 천식, 폐암을 동반한 COVID-19 환자의 삶 의 질을 항상시키는 데 도움이 될 수 있다(Liu et al., 2020).

\section{COVID-19의 감염 경로 및 치료}

COVID-19에 대한 유전체 계통 분석은 완벽하진 않지 만 이를 토대로 바이러스의 특징과 침투 경로를 유추할 수 있게 만들었다. 분석 결과 COVID-19는 SARS-CoV-1, MERS-CoV와 동일하게 사람 및 다양한 동물 종에서 확 인되는 베타코로나바이러스 속(genus)에 해당하는 새로 운 바이러스로 밝혀졌다(Lan et al., 2020). 코로나바이러스 genus는 이름에서 유추할 수 있는 것처럼 투과전자현미 경으로 관찰하였을 때 바이러스 바깥 표면에 왕관 모양 (crown)의 스파이크 단백질 돌기를 특징적으로 관찰할 수 있다. COVID-19, SARS-CoV-1, 그리고 MERS-CoV는 스 


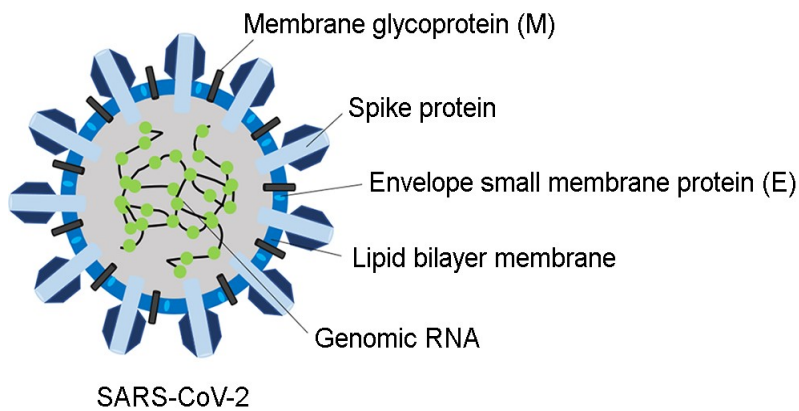

Fig. 4. Cartoon representation of SARS-CoV-2 viral structure. The figure made in Biorender. This figure has been reproduced with permission from ACS publications (Schrank et al., 2020).

파이크 유전자에서 $93 \%$ 이상의 서열 동일성을 나타내며 이 스파이크 단백질은 이용해 숙주세포의 수용체와 결합 하여 세포 안으로 침투하여 병원성을 일으키는 바이러스 $\mathrm{RNA}$ 을 전달하게 된다. 각기 표적이 되는 수용체의 종류 와 결합 정도에 따라 병원성이 다르게 나타나게 된다(Fig. 4). MERS-CoV의 경우 DPP4 (Dipeptidyl Peptidase4)를 수 용체로 활용하고 SARS-CoV-1과 COVID-19는 모두 안지 오텐신 II 전환효소(ACE-2)를 통해 숙주세포에 부착한다 (Cui et al., 2019). 특히 COVID-19는 ACE-2에 SARS-CoV-1 보다 더 강력하게 부착하는 것으로 밝혀져 ACE-2 수용 체의 COVID-19 감염증에 미치는 중요성에 대해 시사했 다. 이러한 차이점이 COVID-19 감염증이 SARS나 MERS 와 비교하여 더 빠르게 확산되는 원인으로 제시되고 있다. 이외에도 감염 단계에서 proprotein convertases (furin), extracellular proteases (elastase), cell surface proteases (TMPRSS2), 그리고 lysosomal proteases (cathepsin)와 같은 여러 가지 효 소가 COVID-19의 세포 내 침투를 돕는 것으로 밝혀졌다 (Li, 2016). 침투한 바이러스는 새로운 바이러스 완성체를 구성할 유전 정보를 지니고 있는 RNA 유전자를 복제해 나가 증식하고 새로운 세포를 감염시킨다. 최근 국내 연 구진이 COVID-19의 모든 RNA전 사체를 분석하여 Cell 지에 보고한 바 있다(Kim et al., 2020). 이 연구 결과를 통 해 COVID-19의 하위 유전체 RNA (ORFS, ORFE, ORFM, ORFN, ORF3a, ORF6, ORF7a, ORF7b, ORF8) 9개로 구성되 어 있음을 확인하였다.

COVID-19는 어떤 연령의 개인에게도 감염시킬 수 있 다고 알려져 있지만 최근 ACE-2 발현 정도가 질병에 심 각성에 미치는 상관관계를 주장하는 보고가 있다(Chen et al., 2020). ACE-2는 일반적으로 상·하 호흡기, 심근, 위장
점막을 포함한 다양한 조직에서 정상적으로 발현하고 있 으며 인간의 건강과 질병에 미치는 역할에 대해 충분히 밝혀지진 않았지만 폐, 혈압, 심장 기능 규제에 관여하고 있을 것으로 추측된다(Ciaglia et al., 2020). 설치류를 이용한 동물 실험에서는 ACE-2는 외부 자극에 인한 심각한 폐 손상으로부터 동물을 보호하는 것으로 나타났고, 노화가 진행될수록 $\mathrm{ACE}-2$ 의 수치는 감소하는 것으로 보고되었다 (Xie et al., 2006). 이는 어린이나 젊은 층이 노인 층에 비하 여 COVID-19 감염증의 심각성이 낮게 나타나는 것에 대 한 부분적인 설명이 될 수 있다. 흥미롭게도 COVID-19 감염 위험이 높고 COVID-19에 의한 치사율이 높게 보고 되는 $\mathrm{COPD}$ 환자나 흡연자의 기도에서 ACE-2의 유전자 발현 수준을 조사한 결과 오히려 그 발현이 크게 증가한 것으로 나타났다(Leung et al., 2020). 즉 ACE-2의 증가는 숙주를 급성 폐 손상으로부터 보호하는 데 유용할 수 있 지만, 만성적으로 이것은 환자들로 하여금 ACE-2 수용체 를 이용한 COVID-19의 감염의 위험을 증가시키는 경향 을 나타낼 수 있음을 시사한다. 더 밝혀져야 할 부분이 많 지만 중요한 것은 $\mathrm{ACE}-2$ 의 균형을 맞추는 것이 COVID19 감염의 방지와 치료에 유용할 수 있다는 것이다.

아직 COVID-19 감염증에 대한 표준화된 치료법은 없으 나, 주로 감염자를 격리하여 지지적 치료(supportive treatment)를 통한 증상완화를 시행하고 있다. 특이적인 항 바 이러스제도 없기 때문에 에볼라, 말라리아, HIV 치료제 등 을 제한적으로 사용하고 있다(Ahsan et al., 2020). COVID19 감염으로 유도된 호흡부전으로 혈중 산소 포화도가 현저하게 떨어져 있는 중증 환자의 경우 고압 산소 치료 (HBOT; Hyperbaric oxygen therapy)를 사용하여 신체에 산소 를 공급해주면 상태가 호전된다는 보고가 있다(Geier and Geier, 2020). 확진자의 대부분이 림프구저하증(lymphocytopenia)을 보이기 때문에 무너진 면역 체계를 회복시키기 위한 면역치료법도 하나의 대안으로 제시되고 있다. 실제 국내 연구진이 완치자의 혈장과 스테로이드를 COVID-19 중증 환자에게 주입한 결과 상태가 호전됨을 보고한 바 있다(Ahn et al., 2020). 이외에도 COVID-19 감염이 ACE-2 수용체의 결합을 통해 이뤄진다는 점을 이용하여 ACE-2 수용체 차단제(Angiotensin II receptor blockers, ARBs)를 사 용하기도 하는데 COVID-19 바이러스 자체가 숙주세포에 결합하는 것을 차단하는 새로운 치료적 접근법이 될 수 있다(Rothlin et al., 2020). 


\section{COVID-19의 진단 및 최근 동향}

COVID-19는 정확한 실체를 밝혀 내기도 전에 전세계 로 급속히 전파되었다. 초기에는 코로나바이러스의 특징 은 관찰할 수 있었으나 신종 여부를 판별할 수 없었기 때 문에 여러 가지 코로나바이러스를 동시에 검출하는 방법 으로 잘 알려져 있는 pan 코로나바이러스 검사법을 통해 환자의 감염을 판별하였다(Vijgen et al., 2008). 이는 바이러 스의 유전자를 증폭시키는 분자 진단법으로 의심 환자에 게 이미 알려진 코로나바이러스 6종(SARS-CoV-1, MERS$\mathrm{CoV}, \mathrm{HCoV}-\mathrm{OC} 43, \mathrm{HKU} 1, \mathrm{NL} 63$, and 229E)에 대한 검사를 진행하여 바이러스의 존재 유무를 확인 후 유전자 분석을 통해 상호 비교하는 배제 진단법에 해당한다. 신종 바이 러스의 확진을 가능하게 하였지만 특이성이 높지 않고 검사 완료까지 2 일 정도의 긴 시간이 소요된다는 단점이 있다. COVID-19에 대한 유전자 정보가 밝혀 짐에 따라 실시간 역전사중합효소연쇄반응(real-time RT-PCR)을 통한 표적 검사법이 활용되었고 이는 검사 시간을 2 6시간으 로 현저하게 줄이고 많은 양을 한번에 검사하여 빠른 진 단에 기여한 것으로 평가된다(Hong et al., 2020). 실험을 수행할 숙련된 연구자나 의료 시설이 잘 구축되어 있었 던 국내 의료 환경을 바탕으로 분자 진단법은 주된 검사 법으로 활용되었으며 5 월 15 일 기준 약 70 만건의 검사 건수를 소화하였다. 경우에 따라 빠른 선별 검사가 필요 할 때 COVID-19 감염 이후 생성되는 $\mathrm{IgG}, \mathrm{IgM}$ 항체를 잡 아내는 면역 진단법도 활용되고 있다(Choe et al., 2020). 항 체 이외에 감염에 따라 증가하는 인터루킨(IL-2, IL-7, and IL-10), TNF-alpha, MCP1 등 사이토카인(cytokine)을 ELISA 방법으로 검출하는 방식도 사용할 수 있다(Li et al., 2020). 이러한 면역 진단법은 정확도나 민감도 면에선 분자 진 단법 보다 떨어질 수 있으나 검사가 간편하고 비용 면 에서 유리하다는 장점이 있다. 중국의 연구팀이 Clinical Infectious Diseases 지에 게재한 연구 내용에 따르면 RT$\mathrm{PCR}$ 기반 분자 진단법과 함께 면역 진단법을 같이 활용 하였을 때 그 정확도와 민감도가 올라가 단점을 극복할 수 있다는 보고도 있다(Guo et al., 2020). 각 나라별 실정을 고려하여 목적에 맞는 효율적인 검사법을 도입하는 것이 전세계의 COVID-19 사태를 타개할 방법일 것이다.

최근 감소 추세에 들어서긴 했지만 꾸준히 신규 감염 사례가 보고되고 있으며 결국 효과적인 백신이 개발되기 전까지 추가 감염 확산을 피하려면 COVID-19 감염자를 신속히 선별하여야 하고 이를 위해 의심 환자에 대한 보
다 강도 높은 검사가 필요하다는 것이 논의되고 있다. 감 염 후 무증상을 보이는 COVID-19 환자도 많이 보고되고 있어 전파를 완전히 차단하는 데 어려움이 있다(Bai et al., 2020). 기존 실시간 RT-PCR 검사법만으로는 무증상 또는 감염 초기의 COVID-19를 완벽히 검출할 수 없고, 최대 2주까지도 위 음성(false-negative) 결과가 나타날 수 있음 이 보고되었다(Rothe et al., 2020). 위 음성 결과의 원인은 불충분한 양의 임상 검체를 획득하였거나 검체로부터 유 전체를 부적절하게 추출하였기 때문이다. 흉부 컴퓨터 단 층촬영(CT; Computerized tomography) 스캔 결과를 임상의 가 판독하여 실시간 RT-PCR 위 음성 사례에서 COVID19 감염을 효과적으로 잡아낼 수 있는 보완적 진단 도구 로 사용될 수 있다(Xie et al., 2020). 이외에도 초기 단계에 서도 COVID-19 감염을 신뢰성 있게 검출할 수 있는 체 외진단(IVD; In-vitro diagnostics) 검사를 개발해 나갈 필요 가 있다. COVID-19 감염 초기 단계에 중요할 특정 바이 오마커를 조사하여 새로운 진단 개발에 활용해야만 할 것이다. Cepheid사는 몇 시간이 걸리는 실시간 RT-PCR을 개선하여 검사 시간을 45 분으로 단축시켰으며 Abbott사 역시 현장검사진단장비(POCT; Point-of-Care test)를 도입하 여 분석 시간을 5 분까지 감소시켰다. 이처럼 진단 시장은 기존 COVID-19 진단법을 보완할 수 있는 신속하고 광범 위한 검사를 새롭게 도입하고 있다(Vashist, 2020). 보완 기 술에 대한 지속적인 노력과 진보는 향후 몇 개월 내에 새로운 COVID-19 검사에 대한 기반을 마련할 것이다.

\section{결 론}

현재 신종 코로나바이러스(COVID-19) 감염증이 전 세 계적으로 급속하게 확산되고 있으며 이를 종식시키기 위 해서는 세계적 동향을 파악할 필요가 있다. 이에 대항하 기 위한 여러 가지 연구에도 불구하고 아직 밝혀져야 할 부분이 많이 남아있으며 국내의 상황은 어느 정도 안 정화되었지만 아직 국제적인 확진자 수는 계속 누적되 고 있기 때문에 지속적인 관심을 기울여야만 한다. SARS, MERS, 그리고 이번 COVID-19 사태를 통해 미래에도 언 제든지 새로운 감염증이 다시 도래할 수 있음을 예측하 고 향후 이를 대비할 수 있는 새로운 진단법, 백신 및 치 료제에 대한 연구가 계속되어야 한다. 이를 위해서는 세 계 연구진의 상호 협력을 바탕으로 제반 연구를 확충해 나가야만 할 것이다. 더 나아가 감염된 국민의 삶의 질을 높이기 위해선 여러 기저질환자를 대상으로 질병의 심각 
성과 관련 있는 상관관계를 파악함으로써 피해를 최소화 할 수 있어야 하고 회복된 특정 생존자에 대한 일상적인 임상 후속 조치를 수행 할 수 있도록 해야 한다. 이에 본 종설에서는 기존에 확립된 여러 임상 정보의 업데이트와 더불어 앞으로 가치가 있을 것으로 예상되는 여러 검사 지표에 대해서 살펴보았다. 이 과학적 지식들이 앞으로 감 염증을 대처하는 데 유용한 참고자료가 될 수 있기를 기 대한다.

\section{ACKNOWLEDGEMENT}

None.

\section{CONFLICT OF INTEREST}

The author has declared no conflict of interest.

\section{REFERENCES}

Ackermann M, Verleden SE, Kuehnel M, Haverich A, Welte T, Laenger F, Vanstapel A, Werlein C, Stark H, Tzankov A, Li WW, Li VW, Mentzer SJ, Jonigk D. Pulmonary vascular endothelialitis, thrombosis, and angiogenesis in COVID-19. N Engl J Med. 2020. 10.1056/NEJMoa2015432.

Ahn JY, Sohn Y, Lee SH, Cho Y, Hyun JH, Baek YJ, Jeong SJ, Kim JH, Ku NS, Yeom J-S, Roh J, Ahn MY, Chin BS, Kim YS, Lee H, Yong D, Kim HO, Kim S, Choi JY. Use of convalescent plasma therapy in two COVID-19 patients with acute respiratory distress syndrome in korea. J Korean Med Sci. 2020. 35: e149.

Ahsan W, Javed S, Bratty MA, Alhazmi HA, Najmi A. Treatment of SARS-CoV-2: How far have we reached? Drug Discov Ther. 2020. 14: 67-72.

Alqahtani JS, Oyelade T, Aldhahir AM, Alghamdi SM, Almehmadi M, Alqahtani AS, Quaderi S, Mandal S, Hurst JR. Prevalence, severity and mortality associated with copd and smoking in patients with COVID-19: A rapid systematic review and meta-analysis. PLoS One. 2020. 15: e0233147.

Bai Y, Yao L, Wei T, Tian F, Jin DY, Chen L, Wang M. Presumed asymptomatic carrier transmission of covid-19. JAMA. 2020. 10.1001/jama.2020.2565.

Barreiro TJ, Perillo I. An approach to interpreting spirometry. Am Fam Physician. 2004. 69: 1107-1114.

Barton LM, Duval EJ, Stroberg E, Ghosh S, Mukhopadhyay S. COVID-19 autopsies, Oklahoma, USA. Am J Clin Pathol. 2020.
153: 725-733.

Bulut C, Kato Y. Epidemiology of COVID-19. Turk J Med Sci. 2020. 50: 563-570.

Chan-Yeung M, Xu RH. Sars: Epidemiology. Respirology. 2003. 8 Suppl: S9-14.

Chen J, Jiang Q, Xia X, Liu K, Yu Z, Tao W, Gong, W, Han JJ. Individual variation of the SARS-CoV2 receptor ACE2 gene expression and regulation. 2020. 2020030191. Preprints.

Choe JY, Kim JW, Kwon HH, Hong HL, Jung CY, Jeon CH, Park EJ, Kim SK. Diagnostic performance of immunochromatography assay for rapid detection of IgM and IgG in coronavirus disease 2019. J Med Virol. 2020. 10.1002/jmv.26060.

Ciaglia E, Vecchione C, Puca AA. COVID-19 infection and circulating ACE2 levels: Protective role in women and children. Front Pediatr. 2020. 8: 206.

Cucinotta D, Vanelli M. Who declares COVID-19 a pandemic. Acta Biomed. 2020. 91: 157-160.

Cui J, Li F, Shi ZL. Origin and evolution of pathogenic coronaviruses. Nat Rev Microbiol. 2019. 17: 181-192.

Daccord C, Touilloux B, Von Garnier C. Asthma and copd management during the COVID-19 pandemic. Rev Med Suisse. 2020. 16: 933-938.

Ganji A, Farahani I, Khansarinejad B, Ghazavi A, Mosayebi G. Increased expression of CD8 marker on t-cells in COVID-19 patients. Blood Cells Mol Dis. 2020. 83: 102437.

Gattinoni L, Chiumello D, Rossi S. COVID-19 pneumonia: Ards or not? Crit Care. 2020. 24: 154

Geier MR, Geier DA. Respiratory conditions in coronavirus disease 2019 (COVID-19): Important considerations regarding novel treatment strategies to reduce mortality. Med Hypotheses. 2020. 140: 109760 .

Giwa AL, Desai A, Duca A. Novel 2019 coronavirus SARSCoV-2 (COVID-19): An updated overview for emergency clinicians. Emerg Med Pract. 2020. 22: 1-28.

Guan WJ, Ni ZY, Hu Y, Liang WH, Ou CQ, He JX, Liu L, Shan H, Lei CL, Hui DSC, Du B, Li LJ, Zeng G, Yuen KY, Chen RC, Tang CL, Wang T, Chen PY, Xiang J, Li SY, et al. Clinical characteristics of coronavirus disease 2019 in China. N Engl J Med. 2020. 382: 1708-1720.

Guo L, Ren L, Yang S, Xiao M, Chang, Yang F, Dela Cruz CS, Wang Y, Wu C, Xiao Y, Zhang L, Han L, Dang S, Xu Y, Yang Q, Xu S, Zhu H, Xu Y, Jin Q, Sharma L, et al. Profiling early humoral response to diagnose novel coronavirus disease (COVID-19). Clin Infect Dis. 2020. 10.1093/cid/ciaa310.

Hong KH, Lee SW, Kim TS, Huh HJ, Lee J, Kim SY, Park JS, 
Kim GJ, Sung H, Roh KH, Kim JS, Kim HS, Lee ST, Seong MW, Ryoo N, Lee H, Kwon KC, Yoo CK. Guidelines for laboratory diagnosis of coronavirus disease 2019 (COVID-19) in Korea. Ann Lab Med. 2020. 40: 351-360.

Huang C, Wang Y, Li X, Ren L, Zhao J, Hu Y, Zhang L, Fan G, Xu J, Gu X, Cheng Z, Yu T, Xia J, Wei Y, Wu W, Xie X, Yin W, Li H, Liu M, Xiao Y, et al. Clinical features of patients infected with 2019 novel coronavirus in Wuhan, China. Lancet. 2020. 395: 497-506.

Kim D, Lee JY, Yang JS, Kim JW, Kim VN, Chang H. The architecture of SARS-CoV-2 transcriptome. Cell. 2020. 181: 914 -921 e910.

Lan J, Ge J, Yu J, Shan S, Zhou H, Fan S, Zhang Q, Shi X, Wang Q, Zhang L, Wang X. Structure of the SARS-CoV-2 spike receptor-binding domain bound to the ACE2 receptor. Nature. 2020. 581: 215-220.

Leung JM, Yang CX, Tam A, Shaipanich T, Hackett TL, Singhera GK, Dorscheid DR, Sin DD. ACE-2 expression in the small airway epithelia of smokers and COPD patients: Implications for COVID-19. Eur Respir J. 2020. 55: 2000688.

$\mathrm{Li} \mathrm{F}$. Structure, function, and evolution of coronavirus spike proteins. Annu Rev Virol. 2016. 3: 237-261.

Li Z, Yi Y, Luo X, Xiong N, Liu Y, Li S, Sun R, Wang Y, Hu B, Chen W, Zhang Y, Wang J, Huang B, Lin Y, Yang J, Cai W, Wang X, Cheng J, Chen Z, Sun K, et al. Development and clinical application of a rapid IgM-IgG combined antibody test for SARS-CoV-2 infection diagnosis. J Med Virol. 2020. 10.1002/jmv.25727.

Liang W, Guan W, Chen R, Wang W, Li J, Xu K, Li C, Ai Q, Lu W, Liang H, Li S, He J. Cancer patients in SARS-CoV-2 infection: A nationwide analysis in China. Lancet Oncol. 2020. 21: 335 -337 .

Liu K, Zhang W, Yang Y, Zhang J, Li Y, Chen Y. Respiratory rehabilitation in elderly patients with COVID-19: A randomized controlled study. Complement Ther Clin Pract. 2020. 39: 101166.

Ma Y, Xu QN, Wang FL, Ma XM, Wang XY, Zhang XG, Zhang ZF. Characteristics of asymptomatic patients with SARS-CoV2 infection in jinan, china. Microbes Infect. 2020. 10.1016/ j.micinf.2020.04.011.

Mehta P, McAuley DF, Brown M, Sanchez E, Tattersall RS, Manson JJ, Hlh Across Speciality Collaboration UK. COVID-19: Consider cytokine storm syndromes and immunosuppression. Lancet. 2020. 395: 1033-1034.

Mo X, Jian W, Su Z, Chen M, Peng H, Peng P, Lei C, Li S, Chen
R, Zhong N. Abnormal pulmonary function in COVID-19 patients at time of hospital discharge. European Respiratory Journal. 2020. 10.1183/13993003.01217-2020: 2001217.

Nikolich-Zugich J, Knox KS, Rios CT, Natt B, Bhattacharya D, Fain MJ. SARS-CoV-2 and COVID-19 in older adults: What we may expect regarding pathogenesis, immune responses, and outcomes. Geroscience. 2020. 42: 505-514.

Oh J, Lee JK, Schwarz D, Ratcliffe HL, Markuns JF, Hirschhorn LR. National response to COVID-19 in the Republic of Korea and lessons learned for other countries. Health Syst Reform. 2020. 6: e1753464.

Rasmussen SA, Watson AK, Swerdlow DL. Middle east respiratory syndrome (MERS). Microbiol Spectr. 2016. 4: 10.1128/ microbiolspec.EI10-0020-2016

Roser M, Ritchie H, Ortiz-Ospina E, Hasell J. Coronavirus Pandemic (COVID-19). 2020. Published online at OurWorldInData.org.

Rothe C, Schunk M, Sothmann P, Bretzel G, Froeschl G, Wallrauch C, Zimmer T, Thiel V, Janke C, Guggemos W, Seilmaier M, Drosten C, Vollmar P, Zwirglmaier K, Zange S, Wolfel R, Hoelscher M. Transmission of 2019-nCoV infection from an asymptomatic contact in Germany. N Engl J Med. 2020. 382 970-971.

Rothlin RP, Vetulli HM, Duarte M, Pelorosso FG. Telmisartan as tentative angiotensin receptor blocker therapeutic for COVID19. Drug Dev Res. 2020. 10.1002/ddr.21679.

Saverino D. COVID-19: Are T lymphocytes simply watching? Panminerva Med. 2020. 10.23736/S0031-0808.20.03934-8.

Schrank CL, Minbiole KPC, Wuest WM. Are quaternary ammonium compounds, the workhorse disinfectants, effective against severe acute respiratory syndrome-coronavirus-2? ACS Infect Dis. 2020. 10.1021/acsinfecdis.0c00265.

Shi F, Yu Q, Huang W, Tan C. 2019 novel coronavirus (COVID19) pneumonia with hemoptysis as the initial symptom: $\mathrm{Ct}$ and clinical features. Korean J Radiol. 2020. 21: 537-540.

Sun L, Liu G, Song F, Shi N, Liu F, Li S, Li P, Zhang W, Jiang X, Zhang Y, Sun L, Chen X, Shi Y. Combination of four clinical indicators predicts the severe/critical symptom of patients infected COVID-19. J Clin Virol. 2020. 10.1016/j.jcv.2020.104431: 104431

Vashist SK. In vitro diagnostic assays for COVID-19: Recent advances and emerging trends. Diagnostics (Basel). 2020. 10.

Vijgen L, Moes E, Keyaerts E, Li S, Van Ranst M. A pancoronavirus RT-PCR assay for detection of all known coronaviruses. Methods Mol Biol. 2008. 454: 3-12.

Vittori A, Lerman J, Cascella M, Gomez-Morad AD, Marchetti G, 
Marinangeli F, Picardo SG. COVID-19 pandemic ards survivors: Pain after the storm? Anesth Analg. 2020. 10.1213/ ANE.0000000000004914.

Wu YC, Chen CS, Chan YJ. The outbreak of COVID-19: An overview. J Chin Med Assoc. 2020. 83: 217-220.

Xie X, Chen J, Wang X, Zhang F, Liu Y. Age- and gender-related difference of ACE2 expression in rat lung. Life Sci. 2006. 78: 2166-2171.

Xie X, Zhong Z, Zhao W, Zheng C, Wang F, Liu J. Chest CT for typical 2019-nCoV pneumonia: Relationship to negative RTPCR testing. Radiology. 2020. 10.1148/radiol.2020200343: 200343.
Xu Z, Shi L, Wang Y, Zhang J, Huang L, Zhang C, Liu S, Zhao P, Liu H, Zhu L, Tai Y, Bai C, Gao T, Song J, Xia P, Dong J, Zhao J, Wang FS. Pathological findings of COVID-19 associated with acute respiratory distress syndrome. Lancet Respir Med. 2020. 8: 420-422.

https://doi.org/10.15616/BSL.2020.26.3.127

Cite this article as: Kim MW. A Review of Recent Trend of COVID-19 Infection and Correlation with Pulmonary Function. Biomedical Science Letters. 2020. 26: $127-135$. 